\title{
Contextual pastoral counselling: Paradigm shifts in practical theological development since the middle 20th century
}

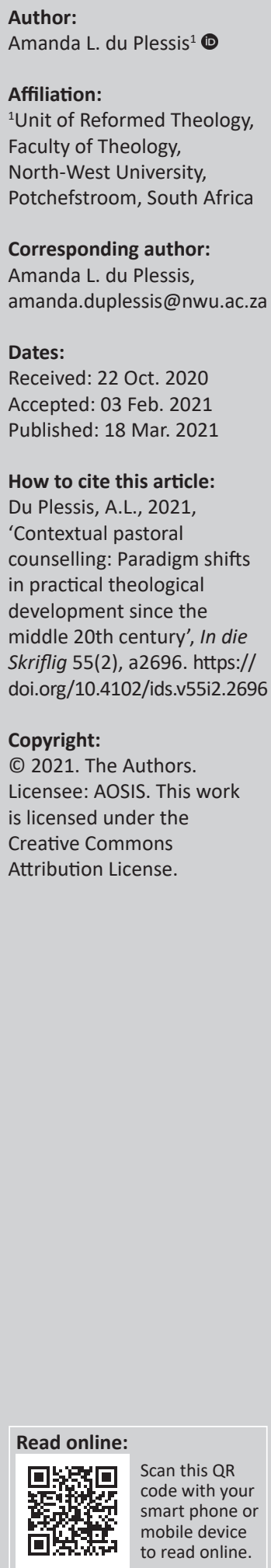

There have been many changes in pastoral care and counselling and pastoral theology since the middle 20th century. At first, the changes were viewed as an evolutionary process as the discipline evolved into an authoritative science. Although it seems as if pastoral care and counselling followed the footsteps of psychology, there were important paradigm shifts towards contextual pastoral counselling based on the Word of God. The major question of this article is, what important paradigm shifts in the development of practical theology since the middle 20th century can be distinguished that are in line with the requirements for contextual pastoral counselling? In an attempt to answer this question, a thorough subject-specific literature study was conducted by looking at prominent scholars' view on the development of pastoral theology. The article is divided into five main parts. The first part focused on the development of practical (and the subdivision, pastoral) theology, with emphases on important paradigm shifts and the work of prominent scholars. The second part focused on the current challenges facing pastoral theology. The third part focused on paradigmatic positions, scientific research markers and approaches, and different layers of meaning unique to pastoral theology. The fourth part focused on diakonia with a religious consciousness of transformative moral or ethical orientation. The article concluded with a reflection on how the paradigm shifts are in line with the requirements of contextual pastoral counselling. The conclusion of the article is that together with the normative deductive aspects of pastoral theology, the inclusion of context-specific empirical experiences is an aspect that must be taken into consideration.

Contribution: The primary contribution of this article is that a systematic description of the important paradigm shifts in the development of practical theology since the middle 20th century was given and brought in evaluation against the requirements for contextual pastoral counselling. The objective was to enhance appropriate theory formation with the aim to focus on the distinctive character of pastoral counselling, and its connectedness to the broader field of practical theological science. These insights link to the focus and scope of the journal, because it contributes to the epistemological dialogue of practical theology.

Keywords: pastoral developments; diakonia; pastoral challenges; pastoral research design; contextual pastoral counselling.

\section{Introduction}

This article is dedicated to Prof. Gert Breed, a Diakonos Christi. Gert, your contribution to the development of pastoral theology at the faculty will always be valued.

The well-known author Harari (2018:x), explored in his first two books (Sapiens and Homo Deus) on the past and the future, concludes that history always carries baggage. He asks if we are still able to understand the world or reality we created. This statement is important when reflecting on several paradigm shifts in the development of practical theology since the middle 20th century, because theologians must be able to understand the world (existential reality) as the space and place of their ministry. In the same line of thought, Meulink-Korf and Van Rhijn (2016:1) warn practical theologians to be careful that their work does not lose touch with daily reality because of an unbalanced view on the theoretical side alone. Already in 1962, Thomas Kuhn (1962:1) alerted that scientific paradigms change constantly in relation to historical developments.

Cultural changes, community and political issues, scientific development in various fields, including theology and behavioural sciences, have contributed to the development of practical theology and especially of the pastoral subdivision. 
The goal of this article is to describe important paradigm shifts in the development of practical theology since the middle 20th century and to evaluate it against the requirements for contextual pastoral counselling.

The objective is to enhance appropriate theory formation with the aim to focus on the distinctive character of pastoral counselling, and its connectedness to the broader field of practical theological science.

In an attempt to answer this goal, the article unfolds into five main parts. The first part focuses on the development of practical theology and pastoral counselling, with emphases on important paradigm shifts. The second part focuses on the current challenges facing pastoral counselling. The third part focuses on paradigmatic positions, scientific research markers and approaches, and different layers of meaning unique to pastoral theology. The fourth part focuses on diakonia with a religious consciousness of transformative moral or ethical orientation. The article concludes with a reflection on contextual pastoral counselling.

\section{Development of practical theology and pastoral counselling}

Whilst this discourse begins with the development of practical theology as a science, the focus will gradually shift to the development of the subdivision pastoral counselling.

Although practical theology as a division of theology was already included as a researchable scientific discipline at universities in 1774, it was met with serious questions about its scientific nature. Planck wrote in 1794 that exegesis, church history and systematic theology were scientific theological disciplines, but that practical theology was only the practical application of the research findings (Heyns \& Pieterse 1990:8).

Initially, practical theology was seen as the practical training of pastors with a one-sided focus on preparing students for their ministry. Schleiermacher secured the place of practical theology as a university sub-discipline of theology. Schleiermacher, viewed by some as the father of practical theology, emphasised the unique intra-disciplinary nature, task and procedures of practical theology as part of theology (Heyns \& Pieterse 1990:9). In his book, Brief Outline of the Study of Theology, he uses the metaphor of a tree to describe the position of practical theology in the broader field of theology (Schleiermacher 1988:4). ${ }^{1}$

The emphasis on the scientific nature of practical theology remained part of the discourse on the identity of practical theology for a long time. Only after the Second World War and the gigantic development in psychology, new approaches and ideas sparked further development in practical theology, especially in the pastoral counselling aspect. The theories or

1 . Schleiermacher (1988) uses a metaphor of a tree and divides theology accordingly into three different perspectives. The roots of a tree indicate the philosophical nature of theology, the trunk of the tree indicates the historical nature of theology and the crown of the tree indicates the practical nature of theology. paradigms that have developed in literature are indicative of how pastoral theology interacts with major historical (cultural) changes, as it is not immune to the unstoppable wave or tsunami of global historical developments. Heitink (1999:15) wrote that paradigm changes 'demonstrate the influence of globalisation, modernist theories, post-modernist culture and post-structuralism with the emphasis on differentiation, secularisation and rationalisation'.

The theory and paradigm developments of pastoral theology have been described thoroughly in scholarly articles and books, for instance in Van der Ven, Dreyer and Pieterse (1997), Van Arkel (2000), Heyns and Pieterse (1990, 1998), Louw (1999, 2013, 2016, 2017), Heitink (1977, 1999), Tidball (1994), MillerMcLemore (2018), Dreyer (2012, 2016) and Osmer (2011). ${ }^{2}$

The article of Van Arkel, Recent movements in pastoral theology, which reflects on developments of the last decade of the 20th century, is especially insightful. Although Van Arkel focuses on the many aspects of pastoral theology that have been influenced by cultural changes, I only elaborate on three of them, as they still determine the discourse on pastoral theology today.

\section{Influence of post-modern culture}

Van Arkel (2000:143-144) describes post-modern cultural developments and highlights important contributions of theologians, such as Doehring (1995:20) who described the influences of culture on pastoral theology as multiple and complex; as well as Gerkin ${ }^{3}$ (1997:76) who pleaded for 'pastoral theologians to find ways to open dialogue between Christian ways of speaking and the ordinary language of people'; and also Tieleman (1995) who pleaded for a broader 'understanding of spirituality as a way to attribute meaning which transcends traditional religion and interacts in a critical-loyal dialogue with culture, rationality and humanity'.

From Van Arkel's article, it is clear that scholars have started to challenge traditional religious views and dogmas, and a focus on the well-being of human beings has become one of the primary aims of pastoral theology.

\section{Moral and ethical character}

The well-being of humans has opened a renewed interest in moral and ethical issues in the ever-changing and increasingly differentiated world of religious, cultural and social diversity. Van Arkel (2000:145) refers to Gerkin (1991) who described the period of pastoral development as a 'climate of confusion and uncertainty', and explained that believers were becoming more and more uncertain about previously accepted normative boundaries. Gerkin's view paved the way to another aim of pastoral theology and he was able to develop a metaphorical, narrative pastoral theology. Years later, Louw (2014:47) would also write about the metaphorical approach to pastoral theology.

\section{Full details of these sources are in the bibliography.}

3.In 2009, Miller-McLemore and Gill-Austern (2009:10) add that ordinary people want to find ways to 'grasp complexities of lived faith'. 
Significantly, Gerkin (1997) emphasised a holistic approach to pastoral care:

That pastoral care needs to be more holistically integrated with the task of social transformation, and that the pastor not only nurtures the process by which the community cares for its members, but also articulates the call of the gospel to be concerned for and actively involved in social ministries that care for the dispossessed, the homeless, and victims of political and economic injustices everywhere. (pp. 74, 127-128)

This widening of the subject matter of pastoral theology has had an enormous impact on the development of pastoral theology. Previously ignored marginalised people, taboo topics and social policies that had kept them in place, became part of the subject matter of pastoral theology (Van Arkel 2000:146). Where the classical functions of pastoral counselling had initially been described as healing, sustaining, guiding and reconciliation (Heitink 1977:17), four more functions were added, namely resisting, empowering, nurturing and liberating (Miller-McLemore 2018:355). Both, MillerMcLemore and Doehring played major roles in revising the functions of pastoral counselling. Currently, both these scholars are known for publications from a feminist paradigm and they have succeeded in raising ethical issues that have to be re-evaluated in the light of power struggles in interpersonal and social contexts (Van Arkel 2000:148).

\section{Effect on methodology}

Another effect of post-modern culture is seen in the methodology of conducting pastoral theology. Whereas the modernist approach tended to be structuralist and positivistic - because it saw results and findings as accurate representations of the subject - post-modernism asked for a post-structuralist, contextual and pragmatic approach. Poststructuralism implies that there is no absolute or universal truth, because life experiences can have different meanings, depending on the context of the experience. The pragmatic element indicates the importance of meanings emerging from reflection on real-life experiences (Doehring 1999:102).

The changed methodology has resulted in another paradigm shift from a deductive to an inductive approach. The view of Van Arkel (2000:146) is that:

$[A] \mathrm{s}$ pastoral theologians we are now reminded not to theologise from doctrines to the lives of people, but to established a norm that inductive, contextual theology methods are as important to respond to and reflect on the experiences of diverse people. (p. 146)

The changed methodology is attributed to feminist and womanist scientific contributions (Van Arkel 2000:147) to such an extent that they have become mainstream contributors and their voices cannot be ignored anymore.

In their work, they have identified seven foci for pastoral theology, namely 'ekklesia and its ministry, marginalised people and taboo topics, female experiences, theological education, soulfulness, violence and systems of care'. They have emphasised the importance of the social, political and religious contexts of care, the importance of caring communities, and indicated the impact of the context on human experience and care, as they identify with the communal-contextual paradigm of pastoral work that was first described by Patton in 1993.

In concluding the first part of the article, I want to add more significant paradigm shifts to the three mentioned by Van Arkel. Patton (1993:4) identified a gradual shift in the paradigm for pastoral counselling from the classical (ecclesiastical), to the clinical and then to a more communalcontextual paradigm. Patton (1993:242) describes pastoral as a 'representative of and accountable to a community of faith, not necessarily being ordained'. The recognition of the third paradigm and re-evaluation of the concept 'pastoral' resulted in shifting ecclesiastical authority away from the clergy towards the Christian community. This shift was described as an effort to move beyond 'care for systems' towards 'systems of care' (Van Arkel 2000:158).

Miller-McLemore (2018:1) expanded on this movement in the early 1990s and re-coined Boisen's well-known phrase, 'living human document', to 'living human web'. The key words for the latter were investigation, interpretation and transformation in the wider political context and pastoral care within the community. With this movement, Miller-McLemore brought the importance of practice to the discourse and critiqued the one-sided focus on theory at training institutions as research to 'address irrelevant theological education', whereas, if the living human web is seen as subject matter, the goal of pastoral theology is to 'address political and social structural injustice'. In response to Miller-McLemore's argument, Dreyer (2012:35) disagreed with her attempt to discredit and reject the academic paradigm. Dreyer stated that the knowledge goal of pastoral theology is both phronesis and episteme, and not either the one or the other.

Just more than a decade before Dreyer's response, Van Arkel (2000) emphasised that:

$[R]$ ather than being threatened by cultural changes ... and the apparent relativistic, subjective and antireligious attitude ... these are seen as creating new opportunities for pastoral theologians to reformulate the principles. (p. 159)

Van Arkel (2000:160) then formulated four distinctive forms of pastoral work, namely mutual care, pastoral care, pastoral counselling and pastoral therapy. Each distinctive form asked for certain skills and greater expertise. The progression between the four forms is indicative of the paradigm shift away from the limited individual focus to 'greater emphasis on the systematic and contextual situation and influence, as well as issues in the community, society and the wider world', but Van Arkel (2000:165) warns that these four levels of pastoral work are interdependent, interacted closely and should not be seen as hierarchical.

McClure (2012) describes another three distinct movements in the communal-contextual paradigm of pastoral work, namely:

$[T]$ he move away from the model of care for an individual by ordained professionals towards the model of care for the 
community and its members by the community and its members, the development of pastoral care as a public theology, and strategic participation rather than personal insight as the goal. (p. 275)

It is clear that paradigms in pastoral theology shifted at the end of the 20th century and that the three main tendencies responsible for the shift were an interest in congregational studies, a call for a new public theology and the rise of liberation movements (Miller-McLemore 2018:348).

In summary, I end the first part with two important conclusions. The first is that of Van Arkel (2000:166) who stated that the most prevalent form of pastoral work active in a specific context will to large extent, depend on the culture or society or situation'. The other is that of Miller-McLemore (2018) who said:

The lesson - that we must hear the voices of the marginalised from within their own contexts - is one pastoral theologians have known all along, and we would do well to sustain it regardless of our changing metaphors. (p. 365)

\section{Challenges to pastoral theology}

The second part of the article focuses on the current situation and challenges to pastoral theology. Where do the paradigm shifts leave us as pastoral theologians? In this part, three challenges will be discussed.

\section{Challenge to understand the context}

I want to start the second part with the following rather long quote from Harari (2018):

Upon reflection, most people concede the existence of at least some significant differences between human cultures, in things ranging from sexual mores to political habits. How then should we treat differences? Cultural relativists argue that difference doesn't imply hierarchy, and we should never prefer one culture over another. Humans may think and behave in various ways, but we should celebrate this diversity, and give equal value to all beliefs and practices. Unfortunately, such broad-minded attitudes cannot stand the test of reality. Human diversity may be great when it comes to cuisine and poetry, but few would see witch-burning, infanticide or slavery as fascinating human idiosyncrasies that should be protected against the encroachments of global capitalism and coca-colonialism. (p. 147)

You may wonder what the above quotation has to do with the discourse on pastoral theology. The cultural context has everything to do with pastoral theology, because human beings' identities - those with which they identify themselves - are crucial historical forces. Culture not only divides the human race, it is also responsible for the upholding of power systems. Mass cooperation of humans needs a shared interest or identity. It is against this background that a deeper understanding of the 'care of systems' versus the call for 'systems of care' challenges pastoral theology. Pastoral care is done within a certain space, within a culture and therefore, it is contextually bound. The first challenge is to understand the context as the space for pastoral care.

\section{Challenge of grounding pastoral theology}

Osmer (2011) adds two more challenges. The first challenge links with the plea of Dreyer for phronesis and episteme:

Practical theology faces the challenge of grounding its identity and purpose in the mission of the church without sacrificing a commitment to scholarship and research that contributes, not only to the church, but also to the common good. (p. 5)

Practical (or pastoral) theologians are challenged to be constructive theologians who work for the common good of all and to 'ground practical theology as a critical, reflective enterprise in the distinctive identity of the Christian community ...' (Osmer 2011:5). In the first part of this article, a paradigm shift towards a more inductive instead of deductive approach has been recognised. Here, attention is given to the importance Osmer assigned to grounded theory as the normative-deductive aspect in pastoral theology. This links with the five different currents in practical theology, as described by Heitink (1999:177), namely the normative-deductive, hermeneuticalmediative, empirical-analytical, political-critical and pastoral-theological currents.

\section{Challenge of the wound of reason}

Osmer (2011) calls the second challenge the 'wound of reason', and describes the immense damage that modern science and technology unleashed upon the global world. Osmer felt so strongly about this that he wrote:

The pretensions of "autonomous man" under the guise of objectivity and progress may be interpreted theologically as an overreaching of a human reason that is held captive by greed and the lust of power. (p. 6)

In an attempt to heal the wound of reason, Osmer (2011:6) brings three aspects to the table. Firstly, he pleads that pastoral theologians acknowledge their grounding in interpretive traditions as it acknowledges the role of values and ethics in inquiry. Secondly, for 'the pressing task ... to imagine and theorise alternatives to a global order totally dominated by the logic and practice of the global marketplace ...' and thirdly, that practical theologians must find 'ways of linking its strong commitment to particular contexts and practice to a larger vision of the whole'.

The challenges that are set to pastoral theologians result in an almost urgent renewing of the uniqueness of pastoral theologies. I recall a remark made by Prof. Daniël Louw at the 2017 SPTSA $^{4}$ conference in Stellenbosch, South Africa. After his presentation, he voiced his fear that pastoral theology in South Africa will die when he retires. Needless to say, this remark was not received well, but looking back at how pastoral theology has evolved and listening to the call for almost a revolution of pastoral theology, I begin to understand his remark. In the last decade, Louw (2013, 2014, $2016,2017)$ has published on the unique paradigm of pastoral 4.Society of Practical Theology in South Africa. 
theology at a high rate. ${ }^{5}$ Another prominent South African scholar who works continuously to formulate a paradigm of practical theology is Prof. Jaco Dreyer. In Dreyer's (2012) response to Miller-McLemore's critique of the academic division of pastoral theology, he not only reminded scholars once again about the prerequisites underlying scientific research, but he also voiced his concern that history is moving towards a post-disciplinary phase.

\section{Prerequisites for pastoral theological research}

The third part of this article focuses on paradigmatic positions, scientific research markers and approaches, and different layers of meaning unique to pastoral theological research.

Dreyer (2012:37) describes the difficulty of understanding academic disciplines and their functioning and refers to scholars (for instance Biglan and Becher, and Krishan) who described certain typologies and perspectives for the various sets of disciplines. He (2012) finds the six paradigmatic angles (or lenses) of Krishan ${ }^{6}$ useful for the formation of a heuristic framework for the debate on the identity and rationality of practical theology and adds:

$[T]$ he six dimensions ... help us to see that disciplines are much more that bodies of knowledge. They are institutionally structured epistemic and social practices, with specific cultures, professional identities, histories and teaching practices. (p. 39)

What the further impact of post-modernism's relativeness on this (institutionally structured epistemic and social practices, with specific cultures, professional identities, histories and teaching practices) will be, only the future will show. Nevertheless, for now, it is important for scholars to ground the theories and paradigms of pastoral theology if we want to stay relevant in our context.

\section{Intra-disciplinary diversity}

If we are honest, we must acknowledge the fragmentation of the discipline of theology at academic institutions in South Africa. Theology has an intra-disciplinary diversity and theology struggles to 'find philosophical, theoretical, and methodological common ground'.7 According to Dreyer (2012:41), 'the fragmentation of disciplines is not only the result of different epistemologies, ontologies and methodologies. It is furthered by the way in which higher education institutions are managed today'. In South Africa,

5.Details of some of the publications are in the bibliography.

6.Krishan (Dreyer 2012:37) describes six paradigmatic angles, 'namely philosophy, anthropology, sociology, history, management and education. The philosophical dimension refers to the organization of knowledge and how knowledge relates to reality ... The anthropological dimension refers to the cultural aspect of disciplines ... The sociological dimension refers to aspects of professionalization and the division of labor.. The historical dimension helps us to understand the rise and fall of of labor ... The historical dimension helps us to understand the rise and fall of disciplines ... The management or organizational dimension helps us to understand the role of market forces, governmental bureaucracy, political pressure ... Th educational dimension refers to the role of teaching and learning regardin disciplines'.

7.It is the words of Sheppard in his description of the intra-disciplinary tension of geography, as quoted by Dreyer (2012:40). the baggage carried by historical periods is especially evident. Pastoral theologians at South African higher educational institutions not only have to find their grounding in the current post-modernistic time frame, but also in the call for decolonisation in the curriculum, which results not only in challenges but also in excellent opportunities, as the emphasis is shifting towards inter- and even trans-disciplinary work.

Another challenge of this paradigm shift is to not sacrifice the unique character of pastoral theology, but to embrace the advantageous opportunity to listen to inter- and transdisciplinary voices. The reference to the unique character of pastoral theology is questionable (Dreyer 2012), as:

[T] he close relationship of practical theology to its ecclesiastical, academic, social, and cultural context has remained a constant; giving varying assessments of the situation, this has led to fundamental differences in how the subject defines itself. (p. 45)

Dreyer (2012:46-52) continues his argument by describing three responses to intra-disciplinary diversity.

Placed on a continuum, the three responses can be seen, on the one hand, as a unifying approach, and on the other hand, a pluralist approach. In the middle of the continuum is a more appropriate dialogic pluralist approach with the aim to view the intra-disciplinary division 'as an opportunity for productive intellectual dialogue'. In following the latter approach, the inherent intra-disciplinary diversity is no longer a stumbling block, but a sign of the 'strong hermeneutical and contextual character' of the pastoral theological discipline.

\section{Basic epistemological dilemma}

Dreyer (2016:90) further reminds us of the conundrum of reflectivity in pastoral theology by drawing attention to the basic epistemological dilemma in our research. The dilemma entails that all knowledge is mediated or interpreted. The researcher's interpretation of the findings has an inherent conflict, because it is based on intellectual bias, scholastic illusion, subjectivity and a positivistic context. The intellectual bias or scholastic illusion reminds us again of what Miller-McLemore said about academic research. Scholastic illusion is the theoreticism of formulating theories that have lost their connection with or grounding in actual practices because of the researcher's privileged and scholastic position (Dreyer 2016:91). Opposed to the modernist positivistic approach, an interpretivist (poststructuralist and post-modern) approach is proposed by Dreyer (2016:92); but he warns that because of researchers' existential situation and intellectual bias, they can actually never escape from subjectivities.

The usual way to avoid subjectivity is to include some form of reflexivity in the interpretation of the findings, but Dreyer (2016:92) warned that our reflexivity 'will always be trapped between apodictic certainty and perpetual suspicion'. The reason is that reflexivity cannot be performed from some kind of neutral or disinterest rational position, as 
epistemological reflection is always rooted in the researcher's worldview or ontology. Pastoral theologians must thus remember that their epistemological reflection is not only coloured by their subjectivity, bias, social location, position in the academic field and their intellectual bias, but also by their ontology (their person, personhood, values, interests, commitments and worldview). Reflexivity, therefore, is always provisional, tentative and an ongoing activity in doing pastoral theological research.

In the following part, the focus shifts closer to home, to the faculty of theology at the North-West University.

In the first three parts, dominant trends in the development of pastoral theology in the last few decades were described that might contribute to a movement towards the contextualisation of pastoral theological training at the faculty. ${ }^{8}$ The objective of the article was set to enhance appropriate theory formation with the aim to focus on the distinctive character of pastoral counselling, and its connectedness to the broader field of practical theological science.

\section{Diakonia with a religious consciousness of transformative moral or ethical orientation}

This article is one of the publications celebrating Prof. Gert Breed's contribution to the development of the pastoral theological curriculum at the faculty, before he retired at the end of 2020. During his time at the faculty, Breed has done in-depth exegetical research on the diakon word group found in the New Testament, together with critical studies of how the concept is used from different viewpoints. I want to mention three of these viewpoints briefly before making it part of the argument for contextual pastoral counselling.

Firstly, Breed (2018:12-18) emphasised that the diakonia of believers is closely related to the diakonia of Jesus Christ. Secondly, believers are considered to be Jesus' diakonoi and therefore they should follow him in his diakonia as his representatives and be willing to die in themselves (Breed 2018:78-86). Thirdly, 1 Corinthians 12 describes an important part of the diakonia of believers (Du Plessis \& Breed 2020). Breed explained it as follows:

In 1 Corinthians 12:4-6, three concepts are connected with each

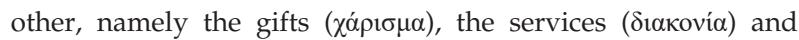
effective working ( $\dot{\varepsilon} v \dot{\varepsilon} p \gamma \eta \mu \alpha)$. The Holy Spirit gives the gifts, the diakonia is that of the Lord Jesus Christ, and when believers use the gifts for diakonia, God (the Father) works all things in everyone. (p. 5)

The realisation of his or her diakonos identity is a basic mindtransforming and heart-generating action that every believer should undergo. Doing pastoral care as a diakonos Christi presupposes a definite hermeneutical perspective of ministering as a diakonos to the other in light of the fact that Jesus Christ died for you. The other is thus forgiven and

8.The contextualisation of pastoral theology refers to the educational process of relating the curriculum to a certain setting, situation or area of application to make
the content relevant, meaningful and useful for learners (Du Plessis \& Breed the content
2020:2). restored to fellowship with God, and is seen as the property of God. It is this hermeneutical perspective that changes the behaviour of the diakonos (Purves 2004:207).

\section{Diakonia involves suffering}

Compassion (splanchnisomai) is deeply rooted in God and is revealed through the diakonia of Jesus Christ. Purves (1989) puts it strikingly:

What we need in our suffering - namely the experience of a companion next to us on the mourning bench - is what we find in God for us in Jesus of Nazareth ... compassion is only possible for us in and through our relationship with God in Christ. (p. 12)

Compassion literally means 'to suffer together', as compassion is defined as the feeling that arises when we are confronted with another's suffering and feel motivated to relieve the suffering (Louw 2013:2). Compassion is nothing less than a form of theological existence in which diakonoi Christi, empowered by the Holy Spirit, partake in Jesus Christ's ministry to and/or of the Father (Purves 1989:133). Billings (2011:2828-2830) elaborated further on the unity in Christ of diakonoi Christi, saying, 'We do not imitate the act of becoming incarnate, but are conformed to Jesus Christ, the incarnate one'.

\section{Diakonos: Representative of and accountable to}

Many proposals for a dialogic pluralist approach are found in literature, although the authors seem unaware that they follow this approach. Consider, for instance, Sills (2016), who remarks that:

[T] he only way in which the church could be ready to meet the challenges of the changing world, is to approach their ministry with an open Bible, an open newspaper and an open mind. (p. 211)

Another example is Louw (2017), who describes a:

$[M]$ ove from a fixed dogmatic approach to a more flexible dynamic of hermeneutics within different cultural contexts; i.e. the dynamics of 'presenting' - a position of 'not knowing' and being open for the mystery and surprise of God's intervention from the 'eschaton' into the vulnerability of the existential here and now of daily events. (p. 11)

With this remark, Louw proposes a paradigm shift away from divine definition to divine infinition. The presence of God through diakonoi is an infinitive mode - a continuously ongoing, ever-present and divine encounter through and by the indwelling Holy Spirit.

Koopman (2007:188) also adds his voice to the dialogic pluralist approach with the emphasis of social issues such as economics, health, racism, religion, crime and ecology as relevant to the South African public pastoral context.

In 2016, Louw (2016:15) quoted the shocking remark of the self-acknowledged atheist, Ludwig Feuerbach, who warned the church against 'an idol of God with "brains," but without 
any passion and "heart"'. It is clear that the dialogic pluralist approach allows the voices of the marginalised and views it to be equally important as the other voices.

\section{Diakonia: Religious conciseness and transformative moral and ethical orientation}

Allowing the marginalised voices means that diakonoi Christi must be with the people suffering. Kearney (2010:21) reminded us that the Hebrew Bible has 36 commands to 'love the stranger' and only two 'to love your neighbour'. Surely, this is indicative that the foci of pastoral ministry expand the borders of the church to the public domain and the marginalised. ${ }^{9}$ Kearney (2010) explains the expansion further:

The understanding of these references is firstly, the stranger is associated with the name of God (Dt 16:11). Secondly, the stranger is invariably linked with allusions to orphans and widows vulnerable and defenceless people (Dt 27:19). Thirdly, the advent of the stranger calls for a 'justice' that seems to go beyond normal agreements of homeland security (Dt 27:19). (p. 21)

Van der Ven et al. (1997:110) already wrote at the end of the 20th century about the broader foci of pastoral care that, firstly, the goal is not 'formulated simply in terms of the extending and intensifying the life of the church', and secondly, 'practical theology is intrinsically determined by the dialectic relation between normativity and empiricism'. Habermas first made the core distinction between 'system' and 'lifeworld' (Van der Ven et al. 1997:112). He related the notion of system to economic and political domains, and the notion of lifeworld to public (culture and society) and private (personhood) spheres of institutional realms. This distinction seems to be the origin of the paradigm shift from 'caring for systems' to 'systems of care', as the main insight propounds the following (Van der Ven 1997):

That system and lifeworld have been uncoupled because of the decreasing influence of the lifeworld, and that the influence of systems on the lifeworld has become so strong that there is evidence of colonization of the lifeworld by the cognitiveinstrumental rationality from the system ... The consequence is that the rationality of knowing in the sphere of culture is increasingly reduced to cognitive-instrumental knowledge, while the danger arises that the normative orientation of solidarity in the social sphere and the expressive orientation of identity and personal responsibility in the sphere of the personality may be completely eliminated from public and private life. (p. 113)

What Osmer (2011:6) called the 'wound of reason' was voiced by Habermas almost two decades earlier, and it is indicative of the hurt because of the one-sided focus on science during modernism. The post-modernist, poststructuralist and interpretivist approach opens a space for pastoral caregivers (as diakonoi Christi) to be passionately present with a religious conciseness and transformative nurturing and liberating, that Miller-McLemore (2018:355) added to the function of pastoral care. moral and ethical orientation. I purposefully use the words, 'to be passionately present' instead of 'minister' ${ }^{10}$

In Philippians 2, Paul describes that believers should have the mind (attitude) of Christ to serve and not demanding to be served. To have the mind of Christ is another - and perhaps the most important - paradigm shift. If pastoral theologians can grasp the full meaning of this principle in their ministry, they will minister in unity with Christ to heal the wounds of the past.

\section{Contextual pastoral counselling}

In the introduction, the goal of this article is given as to describe important paradigm shifts in the development of practical theology since the middle 20th century and to evaluate it against the requirements for contextual pastoral counselling. In this part of the article, the focus will now to be on the latter part of the goal.

To understand contextual therapy, the work of Nagy is of importance. The psychiatrist-psychotherapist, Ivan Boszormenyi-Nagy followed his mentor Kalman Gyárfás' footsteps in stressing the importance of interpersonal relationships in suffering (Meulink-Korf \& Van Rhijn 2016:2). It was after the Second World War that realisations like the healing community, interpersonal psychiatry, interpersonal bond, therapeutic relationship and extended family therapy became markers in the development of contextual psychotherapy.

One important emphasis was that the therapist was seen as a participatory observant and observing participator, and not as an external observing expert any more. Dialogue, instead of change, became the aim of therapy, and a one-sided cognitive approach was rejected. Nagy named his approach 'trust-based therapy', 'dialectical therapy', 'intergenerational therapy' and later 'contextual therapy' with a relationalethical emphasis (Meulink-Korf \& Van Rhijn 2016:7).

Although a significant growth in the development of pastoral counselling can be seen after the Second World War, the modernist perspective had a huge impact on theory formation. It was only in 1948 when the work of Nagy was extended to pastors in the United States of America and the Netherlands. The identified paradigm shifts are proof of this extension. We must remember that reality is always seen as dependent on the observer and this thought has a definite impact on the pastoral counsellor to not lose touch with reality. I therefore want to focus on the multi-dimensional approach to contextual therapy as proposed by Nagy.

According to Nagy (Meulink-Korf \& Van Rhijn 2016:9-17), contextual therapy has four dimensions as frame of reference in the therapeutic conversation. You will recognise that the first three dimensions were always part of the therapeutic

10.Choosing 'to be passionately present' instead of 'minister' is just a matter of rhetoric indicative of an attitude change at cognitive, effective and behavioural levels. 
conversation, but Nagy made the argument that it was too one-sided and that the well-being of humans depends on the well-being of the context. This is in line with Louw who made the paradigm shift from cura animarum to cura vitae caring for the soul to caring for life.

Firstly, the dimension of facts is a perspective on the background, circumstances and social context of the person in need of therapy. It is a sober objective perspective of the life setting and culture in which the person finds himself or herself.

Secondly, the dimension of psychology refers to the needs, drives, affections and emotions of the person. From this perspective, the therapist must enter into dialogue with the person to determine the psychological effect and symptoms based on their interpretation of the circumstance. This second dimension is a dialogue-orientated contribution to understand the interpersonal reality of the person.

Thirdly, the dimension of interaction or transaction refers to the mutual influence of behaviour and communication in the network of relationships. This dimension has a systematic approach in a circular intergenerational effect, where the dialogical conversation is between all the role-players. Communication itself has two distinct dimensions, that is, the content and the relationship, which influence each other and the message. In this third dimension, the therapist comes from a position of 'not knowing' and tries to understand a person's behaviour and actions in a certain context or group. The therapist must also be aware of the effect of power structures or systems, for example, coalition, strategy, boundaries, control, under-dog, top-dog, respective positions as to gender, sexuality and so on.

The fourth dimension is motivation. Nagy acknowledged the first three dimensions (as intra-psychic and interactional direction to psychotherapy), but asked another question about what motivates a person's behaviour. He found that where one person would respond with resilience to healing, another would stay the victim of the same circumstances. It is exactly this fourth dimension that links to contextual pastoral counselling, because the motivational root of behaviour is found in the free will of an individual. Human beings have a freedom and the responsibility to choose. The dimension of motivation is actually a dimension of relational ethics, based on the 'I ... Thou' concept. It entails a form of intrinsic justice, which is ultimately determined by a dynamic balance of giving and receiving in existential relationships.

My thesis is that pastoral theologians must familiarise themselves with the paradigm shifts of the last century (especially from the middle 20th century up to the current time) and re-evaluate their point of departure by considering these challenges. Some key concepts deductible from the paradigm shifts are communal-caregiving, metaphorical, narrative pastoral theology, cultural experiences, empowering, liberating, real-life experiences, existential realities, soulfulness, systems of care, plurality, multi-cultural, multi-disciplinary and so on. These concepts are directions for contextual pastoral counselling. In doing pastoral theological research, a clear articulation of the perspective (philosophical, anthropological, sociological, historical and managerial and educational approach), strategy (inductive or deductive), methodology and data collection technique (literary and empirical aspects), approach (unifying, pluralist or dialogic pluralist) and the demarcation of your setting (location, space or place and boundaries) can only contribute to the validity and relevance of your research. The formulation of 'general' pastoral guidelines - as if one size fits all - is something of the past and only contributes to irrelevant formation of theories. The foci of pastoral theology are too complex and multi-layered for generalisation.

\section{Conclusion}

Taking all the above into consideration, the following conclusions can be made as important for contextual pastoral counselling. The paradigm shifts in the development of pastoral theology are important in identifying the identity, functions and nature of contextual pastoral counselling.

Pastoral care and counselling is a ministry in which believers should care for fellow human-beings. It is based on the love commandment of God as it is described in Matthew 25:45 ( $\ldots$ whatever you did for one of the least of these ...'). Therefore, the setting of the ministry of pastoral care and counselling is both the church and the broader society or community. Pastoral caregivers must be a voice for the voiceless and marginalised.

The expansion of the setting outside the borders of the church rests on the call for believers to be a light in darkness, to bring hope in distress, to be involved in real-life issues and suffering in the world, to be a voice in the dessert. There was a gradual paradigm shift in the subject of pastoral care from caring for the soul to caring for life, and from caring for the living human document to caring for living human web.

Pastoral care always takes place within a certain context and culture, and the pastoral caregiver must have an understanding of the network of relationships and the interconnectedness of life within culture. A contextual hermeneutical paradigm is thus important.

Pastoral caregivers have to approach the community as a participatory observant and observing participator from a perspective of 'not-knowing'. Pastoral caregivers have to master the carefully balanced art to journey with fellow human beings through all phases of life. The pastoral care relationship is based on trust that is built through being present in the life circumstances of those ministered to. Key concepts for being-with-the-other are, for instance, attitude of empathy, verbal and non-verbal communication, personal 
encounter, respect for life, bringing of hope, sensitivity, wisdom and discernment, comforting, liberating, reconciling, emancipation, Coram Dei and so on.

Pastoral caregiving as a healing ministry has their own identity and functions, based on normative-deductive, hermeneutical-mediative, empirical-analytical, politicalcritical and pastoral-theological viewpoint in the reflection on existential realities and various nuances.

Pastoral caregiving will always take place from the perspective of our belief in God, as indicative of the metaphorical approach in the pluralistic dialogical pastoral conversation. Pastoral care takes place under the guidance of the Holy Spirit, who not only guides the pastoral caregiver, but also the person ministered to. Obedience and submission to the Holy Spirit activate their intrinsic justice to act in a relational ethical manner to facilitate healing. Pneumatology is unique to contextual pastoral counselling.

\section{Acknowledgements Competing interests}

The author declares that they have no financial or personal relationships that may have inappropriately influenced them in writing this article.

\section{Author's contribution}

A.L.d.P. is the sole author of this research article.

\section{Ethical considerations}

This article followed all ethical standards for research without direct contact with human or animal subjects.

\section{Funding information}

This research received no specific grant from any funding agency in the public, commercial or not-for-profit sectors.

\section{Data availability}

Data sharing is not applicable to this article as no new data were created or analysed in this study.

\section{Disclaimer}

The views and opinions expressed in this article are those of the author and do not necessarily reflect the official policy or position of any affiliated agency of the author.

\section{References}

Becher, T., 1994, 'The significance of disciplinary difference', Studies in Higher Education 19(1), 151-161. https://doi.org/10.1080/03075079412331382007

Biglan, A., 1973, 'The characteristics of subject matter in different academic areas', Journal of Applied Psychology 57(1), 195-203. https://doi.org/10.1037/h0034701

Billings, J.T., 2011, Union with Christ: Reframing theology and ministry for the church, Baker Academic, Grand Rapids, MI.

Breed, G., 2018, 'The Diakon word group in the New Testament and congregational ministry', PhD dissertation, Radboud University.
Doehring, C., 1995, Taking care: Monitoring power dynamics and relational boundaries in pastoral care and counselling, Abingdon, Nashville, TN.

Doehring, C., 1999, 'A method of feminist pastoral theology', in B.J. Miller-McLemore \& B.L. Gill-Austern (eds.), Feminist and womanist pastoral theology, p. 102 Abingdon, Nashville, TN.

Dreyer, J.S., 2012, 'Practical theology and intra-disciplinary diversity: A response to Miller-McLemore's five misunderstandings about practical theology', International Journal of Practical Theology 16(1), 34-54. https://doi.org/10.1515/ijpt-2012-0004

Dreyer, J.S., 2016, 'Knowledge, subjectivity, (de)coloniality and the conundrum of reflexivity', in J.A. Mercer \& B.J. Miller-McLemore (eds.), Conundrums in practical theology, pp. 90-109, Brill, Leiden.

Du Plessis, A.L. \& Breed, G., 2020, 'Expressive therapy in contextual pastoral care and counselling', In die Skriflig 54(1), 1-7. https://doi.org/10.4102/ids.v54i1.2562

Gerkin, C.V., 1991, Prophetic pastoral practice: A vision of life together, Abingdon, Nashville, TN.

Gerkin, C.V., 1997, An introduction to pastoral care, Abingdon, Nashville, TN

Harari, Y.N., 2018, 21 lessons for the 21st century, Jonathan Cape, London.

Heitink, G., 1977, Introduction to pastoral theology and psychology, Kok, Kampen.

Heitink, G., 1999, Practical theology: History, theory, action domains: Manual for practical theology, Eerdmans, Grand Rapids, MI.

Heyns, L.M. \& Pieterse, H.J.C., 1990, A primer in practical theology, Gnosis, Pretoria.

Heyns, L.M. \& Pieterse, H.J.C., 1998, Eerste treë in praktiese teologie, Gnosis, Pretoria.

Kearney, R., 2010, Anatheism: Returning to God after God, Columbia University Press, New York, NY.

Koopman, N., 2007, 'Public theology in South Africa: A Trinitarian approach', International Journal of Public Theology 13(1), 188-209. https://doi. org/10.1163/156973207X207335

Krishan, A., 2010, 'What are academic disciplines? Some observations on the disciplinarily versus inter-disciplinarily debate', NCRM Working Paper, National Centre for Research Methods, viewed 17 October 2020, from http://eprints.ncrm. ac.uk/783/.

Kuhn, T., 1962, The structure of scientific revolutions, Chicago University Press, Chicago, IL.

Louw, D.J., 1999, A mature faith-spiritual direction and anthropology in a theology of pastoral care and counselling, Peeters, London.

Louw, D.J., 2013, 'Cura vitae: The hermeneutics of spiritual healing and the beautification of life', Scriptura 112(1), 1-16. https://doi.org/10.7833/112-0-60

Louw, D.J., 2014, 'Theory formation within the interplay between pastoral theology and practical theology: Towards a hermeneutics of care and counselling', The Pastoral Journal for Life Care and Spiritual Healing, vol. 1, pp. 47-72.

Louw, D.J., 2016, 'The refugee dilemma and migrant crisis: "Charity begins at home" or "Being home to the homeless"? The paradoxical stance in pastoral caregiving and the infiltration and perichoresis of compassion', HTS Theological Studies 72(2), 1-23. https://doi.org/10.4102/hts.v72i2.3267

Louw, D.J., 2017, 'Practical theology as life science: Fides Quaerens Vivendi and its connection to Hebrew thinking (Hālak)', In die Skriflig 51(1), a2239. https://doi. org/10.4102/ids.v51i1.2239

McClure, B., 2012, 'Pastoral care', in B.J. Miller-McLemore (ed.), The Wiley-Blackwell companion to practical theology, pp. 269-278, Blackwell, Malden, MA.

Meulink-Korf, H. \& Van Rhijn, A., 2016, The unexpected third. Contextual pastoral, counselling and ministry: An introduction and reflection, Christian Literature Fund Publishers, Wellington, Cape Town.

Miller-McLemore, B.J., 2018, 'The living human web: A twenty-five year retrospective', Pastoral Psychology 67(3), 336-370. https://doi.org/10.1007/s11089-018-0811-7

Miller-McLemore, B.J. \& Gill-Austern, B.L. (eds.), 2009, Feminist and womanist pastoral theology, Abingdon, Nashville, TN.

Osmer, R.R., 2011, 'Practical theology: A current international perspective', HTS Theological Studies 67(2), 1-7. https://doi.org/10.4102/hts.v67i2.1058

Patton, J., 1993, Pastoral care in context: An introduction to pastoral care, Westminster John Knox Press, Louisville, KY.

Purves, A., 1989, The search for compassion: Spirituality and ministry, Westminster John Knox Press, Louisville, KY.

Purves, A., 2004, Reconstructing pastoral theology: A Christological foundation Westminster John Knox Press, Louisville, KY.

Schleiermacher, F., 1988, Brief outline of the study of theology, Wipf \& Stock, New York, NY.

Sills, M.D., 2016, Hearts, heads and hands, B\&H Publishing, Nashville, TN.

Tidball, D., 1994, Skilful shepherds: Explorations in pastoral theology, Apollos, Leicester.

Tieleman, D., 1995, Geloofscrisis als gezichtsbedrog: Spiritualiteit en pastoraat in een postmodern cultuur, Kok, Kampen.

Van Arkel, J.T.D.J., 2000, 'Recent movements in pastoral theology', Religion and Theology 7(8), 142-168. https://doi.org/10.1163/157430100X00027

Van der Ven, J.A., Dreyer, J.S. \& Pieterse, H.J.C., 1997, 'Religious consciousness in a transformative perspective', International Journal of Practical Theology 1(1), 110-135. https://doi.org/10.1515/ijpt.1997.1.1.110 